\title{
Genetic variation in the vulnerable and endemic Monkey Puzzle tree, detected using RAPDs
}

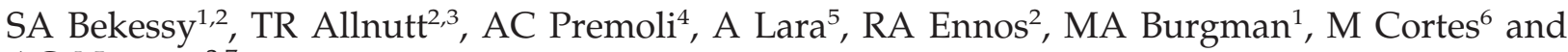 \\ AC Newton ${ }^{2,7}$ \\ ${ }^{1}$ School of Botany, University of Melbourne, Victoria, Australia, 3010; ${ }^{2}$ Institute of Ecology and Resource Management, University \\ of Edinburgh, Darwin Building, Kings Buildings, Mayfield Rd., Edinburgh EH9 3JU, UK; ${ }^{3} J o h n$ Innes Centre, Norwich Research \\ Park, Colney, Norwich NR4 7UH, UK; ${ }^{4}$ Universidad Nacional del Comahue, Laboratorio Ecotono, Quintral 1250, 8400 Bariloche, \\ Argentina; ${ }^{5}$ Instituto de Silvicultura, Universidad Austral de Chile, Casilla 567, Valdivia, Chile; 'Laboratorio de Dendrocronología, \\ Universidad Católica de Temuco, Casilla 15-D, Temuco, Chile; ${ }^{7}$ UNEP-World Conservation Monitoring Centre, 219 Huntingdon \\ Road, Cambridge CB3 ODL, UK
}

\begin{abstract}
Araucaria araucana (Monkey Puzzle), a southern South American tree species of exceptional cultural and economic importance, is of conservation concern owing to extensive historical clearance and current human pressures. Random amplified polymorphic DNA (RAPD) markers were used to characterise genetic heterogeneity within and among 13 populations of this species from throughout its natural range. Extensive genetic variability was detected and partitioned by analysis of molecular variance, with the majority of variation existing within populations $(87.2 \%)$, but significant differentiation was recorded among populations (12.8\%). Estimates of Shannon's genetic diversity and percent polymorphism were relatively high for all populations and provide no evidence for a major reduction in genetic diversity from histori-
\end{abstract}

cal events, such as glaciation. All pairwise genetic distance values derived from analysis of molecular variance $\left(\Phi_{S T}\right)$ were significant when individual pairs of populations were compared. Although populations are geographically divided into Chilean Coastal, Chilean Andes and Argentinean regions, this grouping explained only $1.77 \%$ of the total variation. Within Andean groups there was evidence of a trend of genetic distance with increasing latitude, and clustering of populations across the Andes, suggesting postglacial migration routes from multiple refugia. Implications of these results for the conservation and use of the genetic resource of this species are discussed.

Heredity (2002) 88, 243-249. DOI: 10.1038/sj/hdy/6800033

Keywords: Monkey Puzzle; conservation biology; Araucaria araucana; genetic variation; RAPD; Patagonia

\section{Introduction}

Commonly known as the Monkey Puzzle tree or Pehuén, Araucaria araucana (Molina) K. Koch (Araucariaceae), is an impressively large and long-lived conifer, attaining $50 \mathrm{~m}$ in height, $2.5 \mathrm{~m}$ in girth and reaching ages of at least 1300 years (Montaldo, 1974). Its current distribution spans only three degrees of latitude and is divided between a main area straddling both sides of the Andean divide in Chile and Argentina, and two disjunct populations in the Coastal Range of Chile (Figure 1). The present distribution is a remnant of a more extensive former distribution, which has been severely diminished by logging, human-set fires and land clearance since European colonisation (Veblen, 1982).

The ecology of Monkey Puzzle is disturbance-driven, principally by volcanism, fire, landslides and wind, and it has developed effective adaptations, such as thick bark and epicormic buds, to survive such disturbances (Burns, 1993). Monkey Puzzle is generally dioecious, but may

Correspondence: S Bekessy, School of Botany, University of Melbourne, Victoria, Australia 3010. E-mail: s.bekessy@botany.unimelb.edu.au Received 18 April 2001; accepted 16 October 2001 occasionally be monoecious with predominantly gravitydispersed seed and wind-dispersed pollen. Both seed and pollen are relatively heavy and may not disperse over large distances (Muñoz, 1984; Heusser et al, 1988), although seed dispersal may be assisted by parakeets and other animals (Finckh and Paulsch, 1995). Asexual reproduction by root suckering has been reported (Schilling and Donoso, 1976), but it is unknown how important this process is to population maintenance and expansion (Veblen et al, 1995).

Monkey Puzzle is a socially significant species, producing high-quality timber and providing a unique resource for tourism and recreation. The tree figures importantly in the religion of the native Pehuenche people and is also valued for its large, edible seeds which are extensively collected for local markets (Aagesen, 1998a; Tacón, 1999). Monkey Puzzle has been classified under IUCN guidelines as vulnerable (Farjon and Page, 1999) and is currently officially protected in both Chile and Argentina as well as internationally through listing in Appendix I of the Convention on International Trade in Endangered Species of Wild Fauna and Flora (CITES). Despite its protected status and exceptional ecological, economic and cultural significance, this species continues to experience intense humaninduced pressures, such as grazing, burning and harvesting, both for timber and seeds (Aagesen, 1998b). 


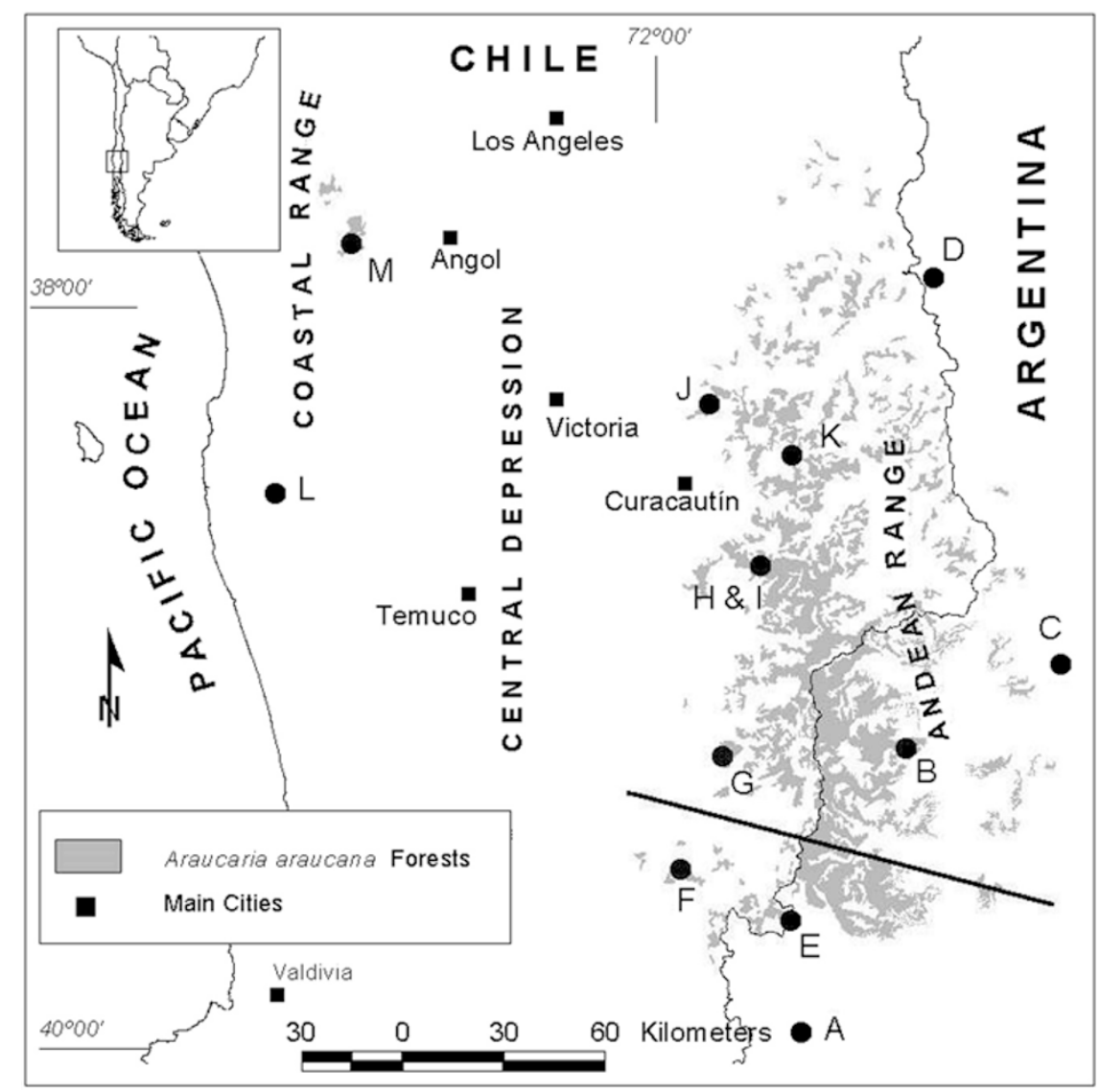

Figure 1 Map showing the position of Monkey Puzzle populations sampled during this investigation (A-M; see Table 1 for details). The diagonal line represents the genetic division found by Marchelli et al (1998) for Nothofagus nervosa.

The preservation of genetic diversity has become a common objective of most conservation programmes (Burgman et al, 1993; Geburek, 1997) and defining genetic diversity within and among natural populations is a necessary first step to achieving this goal (Holsinger and Gottlieb, 1991). Molecular techniques are also becoming increasingly important tools in conservation as a means of identifying otherwise unobservable demographic processes (Haig, 1998) and for understanding the consequences of historical events, such as range expansion, fragmentation and bottlenecks for the distribution of populations (Moritz, 1995).

A large number of methodologies exist for the assessment of genetic diversity in tree species, including several techniques that assess variation of DNA directly (see review by Newton et al, 1999). One of these techniques, RAPDs (random amplified polymorphic DNA) has proved to be particularly valuable in this context, owing to the wide availability of commercial primers and the lack of any need for DNA sequencing information prior to analysis (Williams et al, 1990). The use of RAPDs as markers in population genetic studies for tree species has been well established (Chalmers et al, 1992; Yeh et al, 1995; Gillies et al, 1997; Allnutt et al, 1999) and the ease and efficiency of this method makes it a desirable option (Parker et al, 1998). The limitations of RAPD markers have been summarised by several authors (for example Harris, 1999), including problems associated with reproducibility and product homology. However, RAPDs can provide valuable data about patterns of variation within and among populations of a species (Rieseberg, 1996), provided data are treated correctly (Lynch and Milligan, 1994).

In view of the geographic separation of coastal and Andean populations of Monkey Puzzle and the wide ecological range within its distribution, some degree of genetic differentiation may be expected. Delmastro and Donoso (1980) speculated that racial divergence was probable between coastal and Andean populations and observed some differences in plant form and the degree of vegetative reproduction, although the genetic basis of these traits was not assessed. They also predicted differences across the Andean range, as a result of the major climatic variation; annual precipitation varies from as little as $500 \mathrm{~mm}$ on the Argentinean steppe to as much as $4000 \mathrm{~mm}$ on west-facing slopes in Chile, over an elevation range from $600 \mathrm{~m}$ to almost $2000 \mathrm{~m}$ above sea level.

The genetic diversity of Monkey Puzzle has been investigated in a previous study (Rafii and Dodd, 1998) using proportional composition of foliar epicuticular wax alkanes. A high level of intrapopulation variation was found for the four populations studied, as well as a regional difference between the east and west sides of the Andes, which was greater than the differentiation between Andean and coastal Chilean populations. This was thought to reflect genetic adaptation to the more arid conditions on the eastern side of the Andes, although only four populations were sampled from a very restric- 
ted geographical area. Apart from this preliminary study, nothing is known of the patterns of genetic variation within this species.

In this paper, baseline data are provided on the extent and distribution of RAPD variation within and among natural populations of Araucaria araucana. Additionally, an attempt has been made to identify factors that may have influenced the partitioning of genetic diversity and to make recommendations for conservation planning with respect to protecting the genetic resource of this species.

\section{Materials and methods}

\section{Study sites and sample collection}

Samples were collected from 13 populations from throughout the natural range of the species (Table 1 and Figure 1). Sites were chosen to include areas on both Chilean and Argentinian sides of the Andes and within the Coastal Range of Chile. The locations of populations of Monkey Puzzle in Chile were provided by CONAF et al (1999). The species distribution within Argentina is less well documented and a sampling strategy was designed based on existing distribution maps and consultation with experts.

Leaf samples were obtained from a total of 195 trees from 13 populations. Trees were selected randomly for sampling within each population, but were separated by a minimum distance of $100 \mathrm{~m}$ where possible to avoid sampling closely related or genetically identical individuals. An effort was made to ensure sampled trees were as mature as possible, and preferably larger than $30 \mathrm{~cm}$ diameter at breast height ( $\mathrm{dbh}$ ), although it was necessary to sample smaller trees from some populations where access to larger trees was restricted.

For each population, 15 individuals were sampled, although during the analyses one and two individuals were omitted randomly from the upper and lower Conguíllo populations respectively, to limit the number of samples to 192. This was necessary to enable RAPD analyses of all samples to be undertaken simultaneously, hence reducing error in comparison of RAPD profiles between different PCR runs (Harris, 1999). Five to 10 fresh leaves (depending on leaf size) were collected from each tree and placed into plastic sealable bags containing
$10 \mathrm{~g}$ of silica gel (S4883 silica, Sigma Chemical Company)

\section{RAPD reactions}

The DNA isolation method of Doyle and Doyle (1990) was adapted for Monkey Puzzle leaf tissue. RAPD reactions were performed using the conditions described by Allnut et al (1999), although 2.5 rather than $1.5 \mathrm{mM}$ or $\mathrm{MgCl}_{2}$ was used. Only RAPD bands that could be unequivocally scored were counted in the analysis. Forty arbitrary primers were screened for suitability on a small number of representative individuals (kits OPB and OPE, Operon Technologies, Alameda, CA, USA). Eleven primers which consistently revealed clear patterns were chosen for analysis of the entire sample set. Primers were replicated to ensure that results were repeatable.

\section{Data analysis}

Each PCR product was assumed to represent a single locus and was scored for presence (1) and absence (0). A Jaccard distance matrix was constructed and used as the input file for an analysis of molecular variance (AMOVA) (Excoffier et al, 1992) and to conduct a Principal Coordinates Analysis (The R Package, Vaudor and Legendre, 1991). Variance components were estimated for: (i) within populations; (ii) among populations; and (iii) among regions. Regions were defined as populations within Argentina (east side of the Andes), populations on the Chilean side of the Andes and populations in the Chilean Coastal Range. The genetic distance matrix calculated among populations by AMOVA $\left(\Phi_{S T}\right)$ was used to construct a minimum spanning tree (Felsenstein, 1993). Shannon's Index was calculated following the approach of Allnut et al (1999) and $S_{\text {pop }}$ was calculated as the mean value of $S$ over all the populations sampled and the pooled species-level value was also determined. The percent polymorphic RAPD loci $(\% \mathrm{P})$ was also calculated for each population, as well as the mean value for all populations and a pooled species-level value.

Geographic distances among populations were estimated from coordinates obtained using a geographical positioning system. The relationship between the $\left(\Phi_{S T}\right)$ distance matrix and the matrix of geographic distances

Table 1 Name, location, size and altitude of Monkey Puzzle populations sampled

\begin{tabular}{|c|c|c|c|c|c|c|c|}
\hline Site & $\begin{array}{l}\text { Name and population } \\
\text { identifier }\end{array}$ & Country & Region & Latitude (S) & Longitude (W) & $\begin{array}{l}\text { Approx. size } \\
\text { (No. trees) }\end{array}$ & $\begin{array}{l}\text { Altitude } \\
(m)\end{array}$ \\
\hline A & Curruhue & Argentina & Southern Andes & $39^{\circ} 53^{\prime} 13^{\prime \prime}$ & $71^{\circ} 25^{\prime} 16^{\prime \prime}$ & $<200$ & 1125 \\
\hline B & Largo Pulmari & Argentina & Central Andes & $39^{\circ} 07^{\prime} 15^{\prime \prime}$ & $71^{\circ} 06^{\prime} 06^{\prime \prime}$ & $<500$ & 1025 \\
\hline $\mathrm{C}$ & Primeros Pinos & Argentina & Central Andes & $38^{\circ} 52^{\prime} 51^{\prime \prime}$ & $70^{\circ} 35^{\prime} 10^{\prime \prime}$ & $<500$ & 1670 \\
\hline D & Caviahue & Argentina & Northern Andes & $37^{\circ} 51^{\prime} 70^{\prime \prime}$ & $71^{\circ} 04^{\prime} 19^{\prime \prime}$ & $>1000$ & 1030 \\
\hline $\mathbf{E}$ & $\begin{array}{l}\text { Villarrica-Lake } \\
\text { Quillelhue }\end{array}$ & Chile & Southern Andes & $39^{\circ} 34^{\prime} 95^{\prime \prime}$ & $71^{\circ} 27^{\prime} 80^{\prime \prime}$ & $>1000$ & 1180 \\
\hline $\mathbf{F}$ & Villarrica-Palguin & Chile & Southern Andes & $39^{\circ} 27^{\prime} 53^{\prime \prime}$ & $71^{\circ} 51^{\prime} 15^{\prime \prime}$ & $<500$ & 1215-1335 \\
\hline G & Huerquehue & Chile & Central Andes & $39^{\circ} 09^{\prime} 40^{\prime \prime}$ & $71^{\circ} 42^{\prime} 97^{\prime \prime}$ & $<500$ & $1210-1255$ \\
\hline $\mathbf{H}$ & $\begin{array}{l}\text { Conguillío (low } \\
\text { altitude) }\end{array}$ & Chile & Central Andes & $38^{\circ} 39^{\prime} 02^{\prime \prime}$ & $71^{\circ} 37^{\prime} 18^{\prime \prime}$ & $1800-3500$ & 1080 \\
\hline I & $\begin{array}{l}\text { Conguillío (high } \\
\text { altitude) }\end{array}$ & Chile & Central Andes & $38^{\circ} 39^{\prime} 02^{\prime \prime}$ & $71^{\circ} 37^{\prime} 18^{\prime \prime}$ & $1400-1800$ & $1570-1645$ \\
\hline $\mathbf{J}$ & Tolhuaca & Chile & Northern Andes & $38^{\circ} 12^{\prime} 93^{\prime \prime}$ & $71^{\circ} 48^{\prime} 46^{\prime \prime}$ & $2000-3000$ & 1080 \\
\hline K & Lonquimay & Chile & Central Andes & $38^{\circ} 20^{\prime} 80^{\prime \prime}$ & $71^{\circ} 30^{\prime} 97^{\prime \prime}$ & $1700-2800$ & 1300-1515 \\
\hline $\mathbf{L}$ & Villa Las Araucarias & Chile & Coastal Range & $38^{\circ} 29^{\prime} 43^{\prime \prime}$ & $73^{\circ} 15^{\prime} 80^{\prime \prime}$ & $<200$ & 630 \\
\hline $\mathbf{M}$ & Nahuelbuta & Chile & Coastal Range & $37^{\circ} 49^{\prime} 38^{\prime \prime}$ & $73^{\circ} 02^{\prime} 03^{\prime \prime}$ & $2000-3000$ & 1400 \\
\hline
\end{tabular}


was analysed using a Mantel type matrix randomisation test (Mantel, 1967). In this analysis, distances from one matrix are regressed onto distances in the other matrix being tested. Significance of regressions was evaluated by randomising one of the matrices 1000 times while keeping the other constant and determining the percentage of randomisations resulting in a regression exceeding the observed relationship. If the observed regression exceeded $95 \%$ of the randomly generated regressions, the observed regression was considered statistically significant.

\section{Results}

\section{Genetic diversity}

The 11 primers chosen for analysis were assumed to be a random sample of the genome and generated a total of 65 polymorphic and 17 monomorphic bands. Each of the 192 individuals from the 13 populations was found to have a unique multilocus genotype. No population-specific bands were observed in the data set. The relative degree of diversity in each population as measured by Shannon's index varied from 0.58 (A) to 0.70 (D) (Table 2 ). The mean diversity for all populations $\left(S_{\text {pop }}\right)$ was 0.65 and the pooled species-level value was 0.69 . Percent polymorphic RAPD loci varied from 54.9 (L) to 79.3 (B and $\mathrm{K})$. The mean percent polymorphic loci for all populations was 68.4 and the pooled species-level value was 79.3 (Table 2).

\section{Relationship among populations and regions and with geographic distance}

The partitioning of genetic variation was examined by AMOVA. Although most of the variation $(87.2 \%)$ was found within populations, a significant proportion was attributable to differences among populations (11\%) and regions $(1.77 \%)(P<0.002$ and $P<0.05$ respectively, tested using a 500 replication bootstrap). All pairwise $\Phi_{S T}$ values derived from AMOVA were significant $(P$ $<0.001$ ) when individual pairs of populations were compared (Table 3).

Principal co-ordinate analysis (PCO) was conducted to

Table 2 Shannon's diversity measure $(S)$ and percent polymorphic RAPD loci $(\% \mathrm{P})$ for 13 Monkey Puzzle populations (A-M), mean values averaged over all populations and pooled species-level values. 95\% confidence intervals for Shannon's index are given in parentheses

\begin{tabular}{llll}
\hline Population & \multicolumn{2}{c}{$S(95 \%$ CI $)$} & $\% P$ \\
\hline A & 0.587 & $(0.126)$ & 62.20 \\
B & 0.658 & $(0.108)$ & 79.27 \\
C & 0.690 & $(0.106)$ & 69.51 \\
D & 0.704 & $(0.125)$ & 64.63 \\
E & 0.616 & $(0.123)$ & 71.95 \\
F & 0.634 & $(0.123)$ & 76.83 \\
G & 0.637 & $(0.116)$ & 60.98 \\
H & 0.655 & $(0.112)$ & 71.95 \\
I & 0.695 & $(0.119)$ & 68.29 \\
J & 0.701 & $(0.107)$ & 68.29 \\
K & 0.638 & $(0.119)$ & 79.27 \\
L & 0.590 & $(0.137)$ & 54.88 \\
M & 0.649 & $(0.131)$ & 60.98 \\
Mean, $S_{\text {pop }}$ & $\mathbf{0 . 6 5 0}$ & $\mathbf{( 0 . 1 1 9 )}$ & $\mathbf{6 8 . 3 9}$ \\
Species level & $\mathbf{0 . 6 8 9}$ & $\mathbf{( 0 . 0 9 0 )}$ & $\mathbf{7 9 . 2 7}$ \\
\hline
\end{tabular}

further examine relationships among populations and regions. The first three principal coordinates of RAPD distances described $10.6 \%, 4.9 \%$ and $3.9 \%$ of the variation respectively. Since the PCO explained such a small proportion of the variation in three dimensions, any twodimensional representation would be unreliable. Effectively, the same result is achieved for Nonmetric Multidimensional Scaling ordination for which stress II values remained above 0.4 (Legendre and Legendre, 1983). Data are inherently high dimensional and cannot be reduced to two or three dimensions to aid visual discrimination. However, the minimum spanning tree (Figure 2) is not affected by the high dimensional data because it is generated by the underlying distance matrix.

Although regions defined by the Coastal range, Chilean Andes and Argentinian Andes were found to be significantly different by AMOVA, only $1.77 \%$ of the total variation was explained, and the minimum spanning tree revealed clusters of populations spanning the three regions. The most northerly populations (M, J and D) were grouped together and were different from the most southerly Argentinian population (A) and to the two southern-most Chilean populations (E and F) (Figure 2). The analysis of pairwise $\Phi_{S T}$ values suggested a northsouth trend in the Andean populations, such that the genetic distance tended to increase with increasing latitude (Table 3). Another cluster was found between C, K and $\mathrm{B}$; three populations spanning the Andes. The two most distinct populations were A and L (Figure 2). Conguillío upper (I) and lower $(\mathrm{H})$ were not as distinct as they appeared on the minimum spanning tree; the $\Phi_{S T}$ distance between them is only 0.06 (Table 3 ). The regression of $\Phi_{S T}$ values with geographic distance was significant $(P<0.05)$.

\section{Discussion}

Despite probable historical population contractions (Heusser et al, 1988) and an extremely restricted geographical range, genetic diversity in Araucaria araucana revealed by amplification of total cellular DNA with random primers is extensive. Shannon's Index of diversity and percent polymorphism were both relatively high for all populations (Table 2). Although no extremely low values of Shannon's Index were found, the lowest values were detected for the most strikingly isolated populations with the fewest number of individuals (A and $\mathrm{L}$ from Table 1).

These data indicate that the extent of intraspecific variation found within Monkey Puzzle populations is generally comparable with other tree species studied (Table 4). Despite the power of this study to detect important influences, the current data provide no evidence for genetic bottleneck effects resulting in a reduction in the overall genetic diversity of the species. However, the data also suggest that isolation or reduction in size may have reduced genetic variation within specific populations.

The extent and pattern of genetic variability within and among Monkey Puzzle populations may be affected by historical events, such as glaciation, volcanism and human activity. These events may explain the high level of within-population variation as well as the substantial proportion of among population variation (12.8\%). This proportion is somewhat higher than average given the fact that it is an outbreeding, wind-pollinated species 
Table 3 Pairwise $\Phi_{S T}$ values calculated by AMOVA illustrating differentiation among populations of Monkey Puzzle. A-M refer to the populations sampled (see Table 1)

\begin{tabular}{|c|c|c|c|c|c|c|c|c|c|c|c|c|c|}
\hline$A$ & $A_{0}$ & $B$ & C & $D$ & $E$ & $F$ & $G$ & $H$ & $I$ & $J$ & $K$ & $L$ & $M$ \\
\hline$B$ & 0.1043 & 0 & & & & & & & & & & & \\
\hline C & 0.0964 & 0.0703 & 0 & & & & & & & & & & \\
\hline$D$ & 0.2050 & 0.0866 & 0.1100 & 0 & & & & & & & & & \\
\hline$E$ & 0.1317 & 0.0936 & 0.0745 & 0.1675 & 0 & & & & & & & & \\
\hline$F$ & 0.1980 & 0.1208 & 0.0967 & 0.1942 & 0.0852 & 0 & & & & & & & \\
\hline G & 0.1609 & 0.1184 & 0.0973 & 0.1093 & 0.1182 & 0.1661 & 0 & & & & & & \\
\hline$H$ & 0.1489 & 0.0762 & 0.0712 & 0.0893 & 0.0430 & 0.1128 & 0.1161 & 0 & & & & & \\
\hline I & 0.1715 & 0.0782 & 0.0731 & 0.0629 & 0.1042 & 0.1278 & 0.0610 & 0.0598 & 0 & & & & \\
\hline$J$ & 0.1528 & 0.0677 & 0.1071 & 0.0437 & 0.1110 & 0.1586 & 0.1171 & 0.0462 & 0.0799 & 0 & & & \\
\hline K & 0.1085 & 0.0434 & 0.0709 & 0.1283 & 0.1094 & 0.1094 & 0.1568 & 0.1022 & 0.1077 & 0.1069 & 0 & & \\
\hline$L$ & 0.1835 & 0.1499 & 0.1608 & 0.1680 & 0.1199 & 0.1309 & 0.1561 & 0.1516 & 0.1832 & 0.1687 & 0.1520 & 0 & \\
\hline$M$ & 0.2447 & 0.1360 & 0.1622 & 0.0585 & 0.1955 & 0.1856 & 0.1359 & 0.1407 & 0.1100 & 0.1038 & 0.1634 & 0.1339 & 0 \\
\hline
\end{tabular}

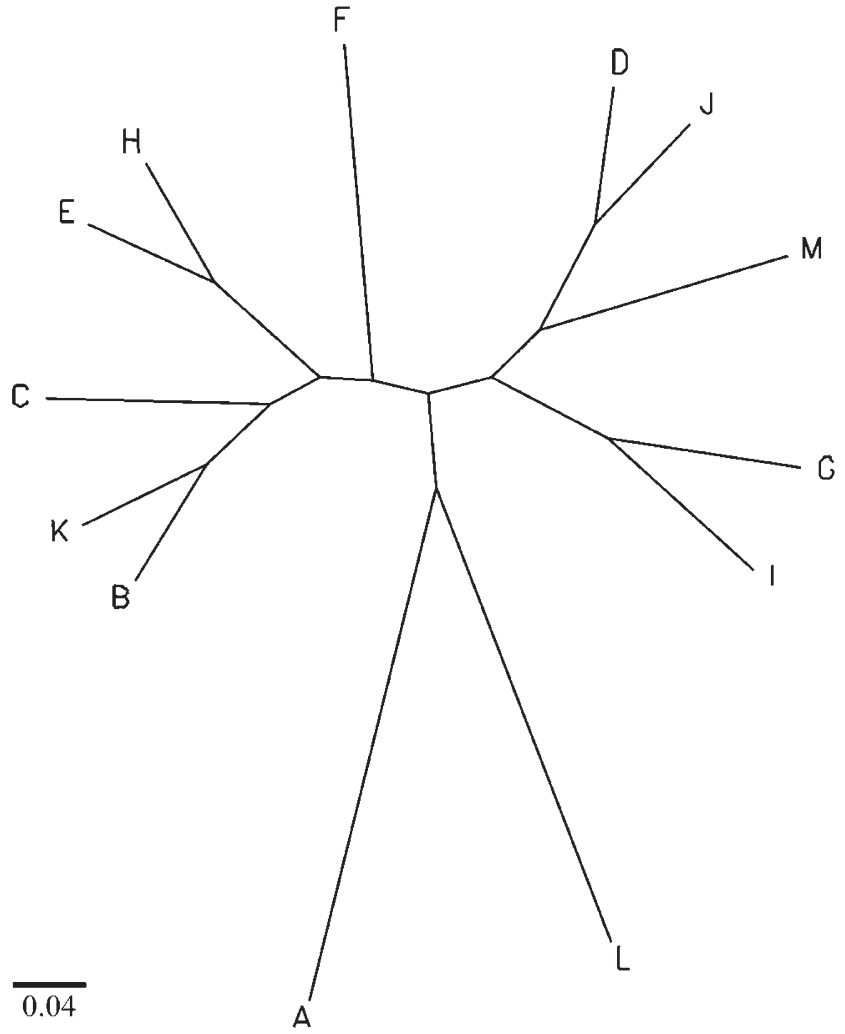

Figure 2 Minimum spanning tree constructed using pairwise $\Phi_{S T}$ values among Monkey Puzzle populations.

(using Hamrick et al's 1992 criteria) with a restricted geographical range.

Volcanism has played an important role in the distribution of the species, with records kept since AD 1640 showing frequent activity of volcanoes within the current distribution of the species (Casertano, 1963). To a lesser extent, seed dispersal by indigenous people may also have influenced the current pattern of genetic variation, particularly for small populations outside the main distribution of the species (Veblen, 1982).

Studies of other southern South American tree species have demonstrated the profound influence of glaciation history in partitioning present day genetic variation (eg, Fitzroya cupressoides (Allnutt et al, 1999; Premoli et al,
Table 4 Shannon's diversity measure $(S)$ and percent polymorphic RAPD loci (\%P) obtained from four and nine different plant species respectively. As a variety of different approaches are used in the calculation of this index, comparisons are only made with other studies that also use the same method

\begin{tabular}{|c|c|c|c|c|}
\hline Species & $\begin{array}{l}\text { Sample } \\
\text { size }\end{array}$ & $S$ & $\% P$ & Reference \\
\hline Araucaria araucana & 192 & 0.65 & 68.4 & This study \\
\hline Pinus chiapensis & 138 & - & 24.5 & $\begin{array}{l}\text { Newton et al, } \\
\text { unpublished data }\end{array}$ \\
\hline Picea mariana & 75 & - & 100 & Isabel et al, 1995 \\
\hline Fitzroya cupressoides & 89 & 0.54 & 72.4 & Allnutt et al, 1999 \\
\hline Podocarpus salignus & 59 & - & 47.5 & $\begin{array}{l}\text { Allnutt, } \\
\text { unpublished data }\end{array}$ \\
\hline Populus tremuloides & 249 & 0.65 & 90.2 & Yeh et al, 1995 \\
\hline Gliricidia sepium & 50 & - & 65.2 & $\begin{array}{l}\text { Chalmers et al, } \\
1992\end{array}$ \\
\hline Cedrela odorata & 68 & 0.42 & 91.5 & Gillies et al, 1997 \\
\hline Carex curvula & 116 & - & 76.8 & Steinger et al, 1996 \\
\hline
\end{tabular}

2000), Nothofagus nervosa (Marchelli et al, 1998) and Nothofagus nitida, N. betuloides and N. dombeyi (Premoli, 1997)). During the Quaternary period the area in which Monkey Puzzle is currently distributed was affected by glacialinterglacial cycles. By the time of the last glacial maximum, 18000 to $20000 \mathrm{BP}$, glaciers covered most of the region, except for the Coastal Range (Heusser et al, 1988). However, evidence from pollen analyses of other species suggests that glaciation occurred in patches leaving localized ice-free areas which provided potential refugia for forest taxa (Markgraf et al, 1995).

Marchelli et al (1998) investigated the genetic variation within and among natural populations of Nothofagus nervosa, a species that is distributed on both sides of the Andes at similar latitudes to Monkey Puzzle. This study revealed a clear distinction between populations distributed south and north of a geographic divide, and this was suggested to provide evidence for multiple glacial refugia. The present study demonstrates a similar trend with a north-south distinction occurring at approximately the same latitude. The three northern-most populations $(\mathrm{M}, \mathrm{J}$ and $\mathrm{D})$ are clustered together and there is a distinction between these populations and the most southerly Argentinian and Chilean populations, $\mathrm{A}$ and $\mathrm{E}$ and $\mathrm{F}$, respectively (Figure 2). Additionally, the genetic distance 
between the northern populations and the Andean populations increased with latitude (Table 3) and a significant relationship was found between geographical and genetic distance among populations. A theory of multiple refugia is also in agreement with other studies investigating the effect of glaciation on the distribution of biota in this region (Moreno et al, 1994; Premoli et al, 2000).

The genetic distinctiveness of the small coastal population of Villa Las Araucarias (L) is an interesting result, particularly given its geographic proximity to the population in Nahuelbuta National Park (M). This population is also ecologically distinctive, occurring at an altitude well below the main distribution of Monkey Puzzle, and on granitic/metamorphic soil rather than typical volcanic soil. Together, these factors provide a strong argument for reviewing the current unprotected status of this population.

\section{Regional differences}

On the basis of Rafii and Dodd's (1998) finding of an east-west distinction and Delmastro and Donoso's (1980) prediction of racial divergence, genetic distinctions may be expected between the Coastal range, Chilean Andes and Argentinian Andes. Although these regions were found to be significantly different by AMOVA, this grouping explains less than $2 \%$ of the variation. Additionally, the minimum spanning tree revealed clusters of populations spanning the three areas (Figure 2). Thus, the present study cannot support Delmastro and Donoso's (1980) prediction of racial divergence.

The contrast between results of this study and of those of Rafii and Dodd (1998) can be explained by differences in the sampling strategy and genetic markers employed. Different types of genetic markers yield different information about genetic diversity and population differentiation (Geburek, 1997). Rafii and Dodd (1998) investigated genetic variation using terpenes, a method that is more likely to detect differences produced by the distinct growing environments on the east compared to the west side of the Andes, in particular the differences in annual precipitation. As a neutral marker, RAPDs are unable to discern differences in adaptive traits, but are more likely to capture variation resulting from historical events, such as postglacial migration (Ennos, 1996). Additionally, Rafii and Dodd (1998) compared four populations, with only one population sampled from the east side of the Andes. The use of such a limited sample highlights a problem with many population genetics studies that infer broad geographic differences based on a sample of a few populations.

\section{Implications for conservation}

Recommendations for conservation based upon the findings of a survey of neutral variation in DNA are inherently limited (Ennos, 1996) and should be treated with caution until other proposed investigations have been completed (eg, quantitative genetics study, investigation of the effects of habitat fragmentation). A particular problem with dominant-recessive marker systems lies in the fact that genetic bottleneck effects may have a much greater effect on allelic richness than on genetic diversity (Petit et al, 1998). Although percent polymorphic loci can potentially be used as an indicator of past demographic changes, a large sample size is required to detect effects. Another limitation is that large sample sizes are required to accurately measure levels of genetic diversity in studies of this kind (Lynch and Milligan, 1994).

However, where this study may contribute to the conservation of Monkey Puzzle is in the identification of several populations that are genetically distinct and currently lack protection. In particular, the most genetically distinct populations $\mathrm{A}$ and $\mathrm{L}$ are highly fragmented, lack adequate protection and are heavily impacted by human activity. Results from the present study also have implications for ex situ conservation of Monkey Puzzle, such as is being undertaken by the International Conifer Conservation Program at the Royal Botanic Gardens, Edinburgh (Gardner, 1999). Because of the significant level of population differentiation, it is recommended that germplasm from different populations should be separately collected and propagated. Additionally, reforestation projects should ensure that local seed is used wherever possible.

On a cautionary note, it is possible that the long life cycle of Monkey Puzzle may be concealing the potential effects of habitat destruction and fragmentation on the level of genetic variation. As with most threatened species that have undergone rapid changes in population size and/or migration rate, molecular genetics studies may be misleading about contemporary population processes (Moritz, 1995). For a species with such a massive generation time, the effects of genetic erosion may not be revealed for hundreds, if not thousands of years.

\section{Acknowledgements}

We are very grateful to CONAF (forest service of Chile) and Administratión de Parques Nacionales, Argentina for permission and assistance to collect samples and to CONAF for providing access to the Catastro GIS data. We are also grateful to the International Conifer Conservation Program (Royal Botanic Garden Edinburgh) for advice and assistance with sample collection, to Peter Ades for assistance with data analysis, to Juan Armesto of the Universidad de Chile for comments and to Patricio Rutherford for preparing the maps, GIS data, and Figure 1. This research was supported by the European Commission funded project SUCRE (Sustainable Use, Conservation and Restoration of Native Forest in Southern Chile and Argentina and South-central Mexico), Framework IV of DGXII, contract number ERBIC18CT970146. Additional funding to Sarah Bekessy was provided by an Australian Postgraduate Award, the University of Melbourne and the Sir Robert Menzies Australian Bicentennial Award. A CITES permit (Convention on International Trade in Endangered Species of Wild Fauna and Flora) was required to export samples from South America (number 020512) and import samples for analysis in the UK (number 225085/01)

\section{References}

Aagesen DL (1998a). Indigenous resource rights and conservation of the Monkey-Puzzle tree (Araucaria araucana, Araucariaceae): a case study from southern Chile. Econ Bot 52: 146-160.

Aagesen DL (1998b). On the northern fringe of the South American temperate forest: the history and conservation of the Monkey-Puzzle Tree. Environ Hist 3: 64-85.

Allnutt TR, Newton AC, Lara A, Premoli A, Armesto JJ, Vergara, 
Ret al (1999). Genetic variation in Fitzroya cupressoides (alerce), a threatened South American conifer. Mol Ecol 8: 975-987.

Burgman MA, Ferson S, Akçakaya HR (1993). Risk Assessment in Conservation Biology, Chapman and Hall: London.

Burns BR (1993). Fire-induced dynamics of Araucaria araucana Nothofagus antarctica forest in the southern Andes. J Biogeogr 20: 669-685.

Casertano L (1963). General characteristics of active Andean volcanoes and a summary of their activities during recent centuries. Seismolog Soc Am Bull 53: 1415-1433.

Chalmers KJ, Waugh R, Sprent JI, Simons AJ, Powell W (1992). Detection of genetic variation between and within populations of Gliricidia sepium and Gliricidia maculata using RAPD markers. Heredity 69: 465-472.

CONAF, CONAMA, BIRF, Universidad Austral de Chile, Pontificia Universidad Católica de Chile and Universidad Católica de Temuco (1999). Catastro y Evaluación de los Recursos Vegetacionales Nativos de Chile. Informe Nacional con Variables Ambientales. Santiago, Chile.

Delmastro R, Donoso C (1980). Review of distribution, variation and utilization of gene resources of Araucaria araucana (Mol.) Koch in Chile. In: Proc. IUFRO Symposio em melboramiento genetico e productividade de especias florestais de rapido crescimento.

Doyle JJ, Doyle JL (1990). Isolation of plant DNA from fresh tissue. Focus 12: 13-15.

Ennos RA (1996). Utilising genetic information in plant conservation programmes. In: Hochberg ME, Clobert J, Barbault $\mathrm{R}$ (eds) Aspects of the Genesis and Maintenance of Biological Diversity, Oxford University Press: Oxford. pp 278-291.

Excoffier L, Smouse PE, Quattro JM (1992). Analysis of molecular variance inferred from metric distance among DNA haplotypes: application to human mitrochondrial DNA restriction sites. Genetics 131: 479-491.

Farjon A, Page CN (1999). Conifers - Status Survey and Conservation Action Plan. IUCN/SSC Conifer Specialist Group: Cambridge, UK.

Felsenstein J (1993). PHYLIP (Phylogeny Inference Package). Department of Genetics, University of Washington, Seattle.

Finckh M, Paulsch A (1995). The ecological strategy of Araucaria araucana. Flora 190: 365-382.

Gardner MF (1999). Managing ex situ conifer conservation collections. In: Andrews S, Leslie SAC, Alexander C (eds) Taxonomy of Cultivated Plants: Third International Symposium, Royal Botanic Gardens, Kew. pp 19-23.

Geburek T (1997). Isozymes and DNA markers in gene conservation of forest trees. Biodivers Conserv 6: 1639-1654.

Gillies ACM, Cornelius JP, Newton AC, Navarro C, Hernandez M, Wilson J (1997). Genetic variation in Costa Rican populations of the tropical timber species Cedrela odorata L., assessed using RAPDs. Mol Ecol, 6: 1133-1145.

Haig SM (1998). Molecular contributions to conservation. Ecology 79: 413-425.

Hamrick JL, Godt MJW, Sherman-Broyles SL (1992). Factors influencing levels of genetic diversity in woody plant species. New Forests 6: 95-124.

Harris SA (1999). RAPDs in systematics - a useful methodology? In: Hollingsworth PM, Bateman RM, Gornall RJ (eds) Molecular Systematics and Plant Evolution, Taylor and Francis: London, pp 211-228.

Heusser CJ, Rabassa J, Brandant A, Stuckenrath R (1988). LateHolocene vegetation of the Andean Araucaria region, Province Neuquen, Argentina. Mt Res Dev 8: 53-63.

Holsinger KE, Gottlieb LD (1991). Conservation of rare and endangered plants: principles and prospects. In: Falk DA, Holsinger KE (eds) Genetics and Conservation of Rare Plants, Oxford University Press: Oxford, pp 195-223.

Isabel N, Beaulieu J, Bousquet J (1995). Complete congruence between gene diversity estimates derived from genotypic data at enzyme and random amplified polymorphic DNA loci in black spruce. Proc Nat Acad Sci USA 92: 6369-6373.
Legendre L, Legendre P (1983). Numerical Ecology. Elsevier: Amsterdam.

Lynch M, Milligan BG (1994). Analysis of population genetic structure with RAPD markers. Mol Ecol 3: 91-99.

Mantel N (1967). The detection of disease clustering and a generalized regression approach. Cancer Res 27: 209-220.

Marchelli P, Gallo L, Scholz F, Ziegenhagen B (1998). Chloroplast DNA markers reveal a geographical divide across Argentinean southern beech Nothofagus nervosa (Phil.) Dim. et Mil. distribution area. Theor Appl Genet 97: 642-646.

Markgraf V, McGlone M, Hope G (1995). Neogene paleoenvironmental and paleoclimatic change in southern temperate ecosystems: a southern perspective. Trends Ecol Evol 10: 143-147.

Montaldo PR (1974). La bio-ecologia de Araucaria araucana (Mol.) Koch. Instituto Forestal Latino-Americano de Investigacion y Capacitacion Boletin 46-48: 1-55.

Moritz C (1995). Uses of molecular phylogenies for conservation. Philos T Roy Soc B 349: 113-118.

Moreno PI, Villagran C, Marquet PA, Marshall LG (1994). Quaternary paleobiogeography of northern and central Chile. Rev Chil Hist Nat 67: 487-502.

Muñoz RI (1984). Analysis de la productividad de semillas de Araucaria araucana (Mol.) C. Koch en el area de Lonquimay IX Region. Tesis para optar al título de Ingeniero Forestal, Universidad de Chile.

Newton AC, Allnutt T, Gillies ACM, Lowe AJ, Ennos RA (1999). Molecular phylogeography, intraspecific variation and the conservation of tree species. Trends Ecol Evol 14: 140-145.

Parker PG, Snow AA, Schug MD, Bootton GC, Fuerst PA (1998). What molecules can tell us about populations: choosing and using a molecular marker. Ecology 79: 361-382.

Petit RJ, Elmousadik A, Pons O (1998). Identifying populations for conservation on the basis of genetic markers. Conserv Biol 12: 844-855.

Premoli AC (1997). Genetic variation in a geographically restricted and two widespread species of South American Nothofagus. J Biogeogr 24: 883-892.

Premoli AC, Kitzberger T, Veblen TT (2000). Isozyme variation and recent biogeographical history of the long-lived conifer Fitzroya cupressoides. J Biogeogr 27: 251-260.

Rafii ZA, Dodd RS (1998). Genetic diversity among coastal and Andean natural populations of Araucaria araucana (Molina), K. Koch. Biochem Syst Ecol 26: 441-451.

Rieseberg LH (1996). Homology among RAPD fragments in interspecific comparisons. Mol Ecol 5: 99-105.

Schilling R, Donoso C (1976). Reproduccion vegetativa natural de Araucaria araucana (Mol.) Koch. Investigaciones Agricultura (Chile) 2: 121-122.

Steinger T, Korner C, Schmid B (1996). Long-term persistence in a changing climate: DNA analysis suggests very old ages of clones of alpine Carex curvula. Oecologia 105: 94-99.

Tacón AC (1999). Analysis economico y ambiental de la recoleccion de pinon de araucaria (Araucaria araucana (Mol.)) Koch. Un estudio de caso en la comunidad de Quinquen. M.Sc. Thesis, Universidad Austral, Valdivia.

Vaudor A, Legendre P (1991). The R Package for Multivariate and Spatial Analysis. Departement de Biologie, Universite de Montreal.

Veblen TT (1982). Regeneration patterns in Araucaria araucana forests in Chile. J Biogeogr 9: 11-28.

Veblen TT, Burns BR, Kitzberger T, Lara A, Villalba R (1995). The ecology of the conifers of southern South America. In: Enright N, Hill R (eds) Ecology of the Southern Conifers, Melbourne University Press: Melbourne. pp 120-155.

Williams JGK, Kubelik AR, Livak KJ, Rafalski JA, Tingey SV (1990). DNA polymorphisms amplified by arbitrary primers are useful as genetic markers. Nucleic Acids Res 18: 6531-6535.

Yeh FC, Chong DKX, Yang RC (1995). RAPD variation within and among natural populations of trembling aspen (Populus tremuloides Michx.) from Alberta. I Hered 86: 454-460. 